\title{
CAPITAL STRUCTURE ANALYSIS TO OPTIMIZE THE PROFITABILITY OF MSMES (CASE STUDY ON MSMES HIKMAH IN SIDOARJO, EAST JAVA， INDONESIA)
}

\author{
Danur Ramadhani $^{1}$, Agus Sukoco ${ }^{2}$, Joko Suyono $^{2}$ \\ ${ }^{1}$ Bachelor of Management Student, Universitas Narotama, Departement of Economics and \\ Business, Jl. Arief Rahman Hakim 51, Surabaya, Indonesia 60117. \\ ${ }^{2}$ Bachelor of Management Lecturer, Universitas Narotama, Departement of Economics and \\ Business, Jl. Arief Rahman Hakim 51, Surabaya, Indonesia 60117. \\ danurramadhani84@gmail.com

\begin{abstract}
This study aims to analyze the capital structure used to optimize profitability in MSME embroidery shoes. This study uses descriptive research with a qualitative approach. The analytical method is used Weighted Average Cost Of Capital (WACC). The techniques of data collection in this research used interview, observation, documentation and triangulation methods. The data that used are financial transaction records and financial statements issued by the company itself. The results showed that UD. Hikmah used the composition of the capital structure consisting of debt of $20 \%, 80 \%$ own capital with a ROE rate of $170 \%$. Optimization results obtained the optimal capital structure composition on the composition of debt $23 \%$ and own capital $77 \%$. By generating a level of profitability that can provide a favorable return for business owners, with the highest calculation of ROE that is equal to $173 \%$ and the cost of capital to be borne is Rp.18.238.000 every year.
\end{abstract}

Keywords: Optimal Capital Structure, Profitability

\section{INTRODUCTION}

A company is said to grow and flourish if the company has the best performance. Both in terms of business performance, a business must also be supported by a mature strategy in all aspects including financial management. One of the important things in financial management is aquisition (finding / obtaining funding sources) both from internal and external sources (Yuliani, 2017). Determination of the use of capital structure is a long-term policy that is very influential on the survival of every large business to MSMEs, but management still does not understand the importance of using the appropriate capital structure to finance business operations (Ardiany \& Topowijono, 2014). Given the capital structure is used to determine the cost of capital which will then be able to determine the level of profitability for the future, then each business actor is expected to be able to arrange the use of capital structure appropriately (optimal).

The optimal capital structure, namely the capital structure that will increase the profitability of the company and this structure generally requires a debt ratio that is lower than the ratio that maximizes the expected EPS (J. Fred Weston, 1996) Seeing the development of MSMEs that continues to increase from year to year, this has not been accompanied by awareness of MSMEs actors in understanding and the importance of analyzing capital structure for their business activities. The use of capital structures in the MSME sector still tends to often use external sources of debt (Debt) which cause high costs of capital to be borne rather than using funding sources originating from internal sources, so that simple and easy to understand analysis is needed to help optimize the extent to which the business can using the composition of the right capital structure (Optimal) using the Weighted Average Cost Of Capital (WACC) analysis method (Britzelmaier, Kraus, Häberle, Mayer, \& Beck, 2013). Weighted Average Cost Of Capital is the weighted 
average cost of capital for all financing sources that the company will use to finance long-term assets (David F. Scott, 2000). The minimum WACC value will produce the maximum level of profitability.

Small business UD.Hikmah experienced problems in the formulation and use of capital structure due to limited internal access to capital itself and limited difficulties in accumulating from own capital. The purpose of the analysis of capital structure optimization analysis using the WACC analysis method for UD.Hikmah. This lesson is to be able to find out the optimal capital structure used or not, considering UD.Hikmah has tried to expand its business by carrying out export activities of its products to China and Korea. Therefore, the decision of sources of funds used to strengthen the capital structure of UD.Hikmah cannot be seen as a simple decision, but has strong implications for what will happen in the development of its business in the future.

Based on the background of the problems described above, the problems that will be examined in this study can be determined, namely:

1. How is the composition of the capital structure on small business UD. Hikmah in Sidoarjo?

2. How to analyze the optimization of capital structure in small business UD. Hikmah in Sidoarjo?

\section{LITERATURE REVIEW}

\section{Capital Structure}

Sources of funds in the company are divided into two categories, namely internal funding sources and sources of external funding. Internal funding sources can be obtained from retained earnings and depreciation of fixed assets and a source of external funding can be obtained from its creditors called debt (Suad Husnan, 2000).

Optimal capital structure that is capital structure that can minimize the use of the average cost of capital, thus maximizing the value of the company (Ardiany and Topowijono, 2016).

David F. Scott, J. (2000) define the capital structure is as the composition and the proportion of long-term debt and equity (stock Preferren and common stock) were designated company.

The capital structure is balancing number-term debt short permanent, debt Long -term, preferred stock and common stock (James C.Van Horne, John M. Wachowicz, 2012).

\section{Cost of Capital}

Cost of capital is closely connected with the concept of the meaning of the required profit level (required rate of return). The capital costs are usually used as size to determine acceptance or rejection something investment proposal (as the discount rate), by comparing rate of return of the investment proposal with the cost of capital. Cost of capital here namely the overall cost of capital (Yasir, Fuad, and Wahida, 2018).

James C. Van Horne (2007: 122) explains athe cost of capital is the rate of return requested on various types of funding and cost Overall capital is The weighted average of each returns The requested (the cost).

Cost of capital, all costs rill which is issued by the company in order to get source fund used to companies investment (Sutrisno, 2011: 150).

\section{Profitability}

Harahap (2015: 304) explain The ratio of earnings or profitability is also the profitability which describe the company's ability to get profit through all abilities, and source that there is such sales activities, cash, capital, number of branches, and so forth.

Profitability ratios is a ratio to assess the company ability in seeking profit. This ratio also provides a measure of the level of effectiveness of management of a company. This is deonstrated by profit generated from sale and investment income. Basically the use of this ratio shows level the efficiency of a company.

\section{MSMEs}

MSMEs are productive economic enterprises that are independent, carried out by individuals or business entities that are not subsidiaries or branches of companies owned (Undang-Undang, 2008).

MSMEs have an important role to play in national development and labor development in Indonesia.

\section{Research Flow Framework}

\begin{tabular}{|c|c|c|}
\hline Determine rese arch topics & \multicolumn{1}{c|}{$\begin{array}{c}\text { Literature Study And The oretical } \\
n\end{array}$} \\
\cline { 2 - 3 }
\end{tabular}

Study OfMSMEs (Observations, Interviews, Documentation. Triangulation). 
Figure 1: Research Flow Framework 


\section{METHODS}

\section{Research Approach}

This study uses descriptive research with a qualitative approach because it describes a real situation and phenomena and the existence of inductive data source retrieval (Sugiyono, 2011).

\section{Data Types}

The type of data collected in this study is in the form of quantitative data, namely data that can be calculated or calculated directly in the form of numbers, on the dimension of value, and others. (Suryana, 2012), The quantitative data in this study include:

1. Financial statements 2018.

2. Sales report 2018.

3. Report on raw material costs 2018

\section{Data Source}

The data source used in this study is Primary data because this study interacts directly with MSMEs by conducting interviews, observation, and study documentation with the owner regarding the description of the current business capital structure and financial statements. Obtained directly from the owner of the UD.Hikmah in the form of balance sheet, income statement, sales report, as well as reports on raw material costs respectively in the period 2018.

\section{Data Collection Techniques}

Data collection techniques used in this study are interviews, observation, documentation and triangulation.

\section{Data Analysis Technique}

Data analysis technique used is the WACC method (Holden, 2002), as follows:

1. Data collection, that is by collecting data from objects examined by observation, interviews, documentation, and triangulation.

2. Calculating cost of debt after tax $(\mathrm{kD})$ owned by MSMEs UD.Hikmah, Formula:

$$
k D=k d(1-t)
$$

3. Calculating cost of equity (kE) owned by MSMEs UD.Hikmah, Formula:

$$
k E=R f+(R m-R f) \beta
$$

4. Calculates capital structure UD.Hikmah, Formula:

$$
\begin{aligned}
\text { Weight Debt (wD) }\left(\frac{\circ}{\circ}\right) & =\frac{\text { Total debt }}{\text { Total Debt }} \times 100 \% \\
\text { Weight Equity (wE) }(\%) & =\frac{\text { Total capital }}{\text { Total Equi }} \times 100 \%
\end{aligned}
$$

5. Calculates the Weighted Average Cost of Capital (WACC), Formula:

$$
\mathrm{WACC}=(\mathrm{WD} \times \mathrm{kD})+(\mathrm{WE} \times \mathrm{kE})
$$

6. Calculates the Cost of Capital UD.Hikmah, Formula:

$$
\text { Cost of Capital }=\text { WACC } \times(D+E)
$$

7. Calculating the profitability level of MSMEs UD. Hikmah, in this case the level of profitability is measured by calculating ROE, with the formula:

$$
\text { Return On Equity (ROE) = Net profit } \times 100 \%
$$

8. Making Optimization of the capital structure in MSMEs UD. Hikmah.

9. Describe and conclude the results of the study. 


\section{RESULT AND DISCUSSION}

To find out the composition of the optimal capital structure at UD. Hikmah, what needs to be done is to collect data that contains MSMEs financial statement data consisting of income statement and preparation in a period of 1 year. From the data obtained will be used to analyze the optimization of the capital structure used by UD. Hikmah.

\section{Income Statement}

Table 1: Income Statement UD.Hikmah period 31 December 2018

\begin{tabular}{|c|c|c|}
\hline \multicolumn{3}{|c|}{$\begin{array}{c}\text { UD. HIKMAH } \\
\text { INCOME STATEMENT } \\
\text { As of } 1 \text { January-31 December } 2018\end{array}$} \\
\hline Sales & & Rp. $2,448,000,000$ \\
\hline Cost of Goods Sold & & Rp. $(1,584,000,000)$ \\
\hline GROSS PROFIT & & Rp. $864,000,000$ \\
\hline \multicolumn{3}{|l|}{ Operating Costs } \\
\hline Employee Salary Costs & \multicolumn{2}{|c|}{ Rp. $139,200,000$} \\
\hline Electricity Costs & \multicolumn{2}{|c|}{ Rp. $6,000,000$} \\
\hline \multicolumn{3}{|l|}{ Raw Material Costs } \\
\hline Maintenance Costs & \multicolumn{2}{|c|}{ Rp. $27,500,000$} \\
\hline Total Operating costs & & Rp. $(311,300,000)$ \\
\hline Earning Before Interest and Tax (EBIT) & & Rp. $552,700,000$ \\
\hline Interest Expense & & Rp. $\quad(6,760,000)$ \\
\hline Earning Before Tax (EBT) & & Rp. $545,940,000$ \\
\hline $0.5 \%$ UMKM Tax & & Rp. $\quad(2,729,700)$ \\
\hline NET INCOME / EAT & & Rp. $543,210,300$ \\
\hline
\end{tabular}

Source: Financial Report UD.Hikmah, data is processed by authors.

From table 1 above, it can be seen that the total sales per year is Rp. 2.448.000.000. For operational costs of Rp.311.300.000. After knowing the total sales and operating costs, then calculating EBIT (earnings before interest and taxes) that is by way of gross profit minus the total operating costs. From the reduction, EBIT was obtained at Rp.552,700,000.- and reduced by interest costs will be obtained EBT results of Rp.545,940,000. The tax that must be paid by MSMEs in accordance with PMK Number 99 is equal to $0.5 \%$ and a net profit of Rp.543,210,300 can be obtained. 


\section{Balance Sheet Report}

Table 2: Balance Sheet Report UD.Hikmah period 31 December 2018

Balance Sheet Report UD.HIKMAH

As of December 31, 2018

\begin{tabular}{|c|c|}
\hline \multicolumn{2}{|l|}{ ASSETS / ASSETS } \\
\hline Cash & Rp. $19,500,000$ \\
\hline Bank & Rp. $35,000,000$ \\
\hline Raw Materials & Rp. $108,600,000$ \\
\hline Inventory & Rp. $42,650,000$ \\
\hline Current Assets & Rp. $205,750,000$ \\
\hline Land & Rp. $19,500,000$ \\
\hline Building & Rp. $125,000,000$ \\
\hline Vehicles & Rp. $27,000,000$ \\
\hline Equipment & Rp. $23,000,000$ \\
\hline Fixed Assets & Rp. $194,500,000$ \\
\hline TOTAL ASSETS & Rp. $400,250,000$ \\
\hline \multicolumn{2}{|l|}{ PASIVA / LIABILITY } \\
\hline Short term Debt & - \\
\hline Long Term Debt & Rp. $80,000,000$ \\
\hline Current Pasiva & Rp. $80,000,000$ \\
\hline \multicolumn{2}{|l|}{ Capital / Equity } \\
\hline Paid up capital & Rp. $117,900,000$ \\
\hline Retained Earnings & Rp. $105,900,000$ \\
\hline Current Profit & Rp. $96,450,000$ \\
\hline Fixed Pasiva & Rp. $320,250,000$ \\
\hline TOTAL PASIVA & Rp. $400,250,000$ \\
\hline
\end{tabular}

Source: Financial Report UD.Hikmah, data is processed by authors.

From the table above, it can be seen the total assets of Rp.400.250.000. - taken from the sum of current assets with fixed assets. Total Pasiva obtained from total debt plus total capital which is equal to Rp.400.250.000. From these results, it can be said that the total assets and total pasiva balance.

Before calculating and determining the optimal capital structure, it must first calculate the parts, namely:

1. Calculating the cost of debt after tax $(\mathrm{kD})$

$$
\begin{aligned}
\mathrm{kD} & =\mathrm{kd}(1-t) \\
& =15 \%(1-0,5) \\
& =0.15 \times 0.995 \\
& =0.1493 \\
& =14.93 \%
\end{aligned}
$$

2. Calculating cost of equity $(\mathrm{kE})$

Description: 1) Small business UD.Hikmah does not have a rate of return on risk-free investment which means equal to 0 . Therefore the formula for calculating capital costs is $\mathrm{kE}=\mathrm{Rf}$

2) $\mathrm{Rf}$ is the rate of return on risk-free investment or BRI's deposit interest reference value. 

Answer : $\quad \mathrm{kE} \quad=\mathrm{Rf}$
$\mathrm{kE} \quad=0.048$
$=4.8 \%$

3. Calculating the capital structure
1) Weight Debt (wD) (\%)

2) Weight Equity (wE) (\%)

$$
\begin{aligned}
& =\frac{\text { Total debt }}{\text { Total Debt + Equity }} \times 100 \% \\
& =\quad \frac{\text { Rp. } 80.000 .000}{\text { Rp. } 400.250 .00} \times 100 \% \\
& =0.20 \\
& =20 \% \\
& =\quad \frac{\text { Total ca }}{\text { Total Equity + Debt }} \times 100 \% \\
& =\quad \frac{\text { Rp. 320.25( }}{400.250 .00(} \times 100 \% \\
& =0.80 \\
& =80 \%
\end{aligned}
$$

4. Calculating the percentage of Weighted Average Cost of Capital (WACC)

$=(\mathrm{WD} \times \mathrm{kD})+(\mathrm{WE} \times \mathrm{kE})$

$=(0.20 \times 0.1493)+(0.80 \times 0.048)$

$=0.02986+0.03832$

$=0.06818$

$=6.818 \%$

5. Calculating Cost of Capital

$$
\begin{aligned}
\text { Cost of Capital } & =\text { WACC } \times(D+E) \\
& =6.818 \% \times \mathrm{Rp} .400,250,000 \\
& =\mathrm{Rp} .17 .873 .000
\end{aligned}
$$

6. Calculating ROE (Return On Equity)

$$
\begin{aligned}
\text { ROE } & =\frac{\text { Net profit after }}{\text { Shareholders Equ }} \times 100 \% \\
& =\frac{543,210,300}{320,250,000} \times 100 \% \\
& =170 \% .
\end{aligned}
$$


7. Engineering simulation of capital structure optimization

Table 3: Simulation of Capital Structure Optimization

\section{SIMULATION OF CAPITAL STRUCTURE OPTIMIZATION}

Description

Composition

\begin{tabular}{|c|c|c|c|c|c|c|}
\hline & $0 \%$ & $20 \%$ & $40 \%$ & $60 \%$ & $80 \%$ & $100 \%$ \\
\hline Debt & 0 & $80,000,000$ & $160,000,000$ & $240,000,000$ & $320,000,000$ & $400,000,000$ \\
\hline EBIT & $552,700,000$ & $552,700,000$ & $552,700,000$ & $552,700,000$ & $552,700,000$ & $552,700,000$ \\
\hline Interest & (0) & $(5,760,000)$ & $(10,816,000)$ & $(14,872,000)$ & $(16,900,000)$ & $(18,811,900)$ \\
\hline EBT & $552,700,000$ & $546,940,000$ & $541,884,000$ & $537,828,000$ & $535,800,000$ & $533,888,100$ \\
\hline $\operatorname{Tax}$ & (0) & $(2,729,700)$ & $(2,709,420)$ & $(2,689,140)$ & $(2,679,000)$ & $(2,669,441)$ \\
\hline EAT & $552,700,000$ & $544,210,300$ & $539,174,580$ & $535,138,860$ & $533,121,000$ & $531,218,660$ \\
\hline Equity & $400,000,000$ & $320,000,000$ & $240,000,000$ & $160,000,000$ & $80,000,000$ & 0 \\
\hline $\begin{array}{c}\text { ROE } \\
\text { (Profitability) } \\
\end{array}$ & $173 \%$ & $170 \%$ & $168 \%$ & $167 \%$ & $166 \%$ & $166 \%$ \\
\hline Capital Cost & $18,238,000$ & $12,113,000$ & $9,243,800$ & $7,824,000$ & $5,387,300$ & 0 \\
\hline Cost Of Capital & $18,238,000$ & $17,873,000$ & $20,059,800$ & $22,696,000$ & $22,287,300$ & $18,811,900$ \\
\hline
\end{tabular}

Before determining the optimal capital structure, in the calculation above it can be seen the composition of the capital structure of UD.Hikmah in 2018, namely the composition of debt $20 \%$ or Rp. 80.000.000.- with an interest of 0.4 per month. If calculated in one year, the debt interest is $4.8 \%$ per year. From the composition of debt used $20 \%$ obtained EBT of Rp. 545.940.000.- after that the MSMEs tax is reduced by $0.5 \%$ which has been stipulated in PMK 99.

The result of the deduction is obtained by EAT / net profit after tax of Rp.543.210.300. If the composition of debt is $20 \%$, then the composition of the capital is $80 \%$ or Rp.320.000.000.- (rounding) and obtaining a ROE of $170 \%$ obtained from the proceeds between EAT and own capital and generating capital costs of Rp.17,873,000. From the above composition, an optimal capital structure calculation can be made, as follows:

Table 4: Optimization of Capital Structure

\begin{tabular}{|c|c|}
\hline Description & Value \\
\hline Difference in overall capital costs between $40 \%$ and $20 \%$ & Rp. $2,186,800$ \\
\hline Difference in overall capital costs between $0 \%$ and $20 \%$ & Rp. $\quad 365,000$ \\
\hline Comparison of overall capital costs & $17 \%$ \\
\hline $40 \%$ and $20 \%$ Debt Difference & Rp. $80,000,000$ \\
\hline $17 \%$ of the debt composition of $80,000,000$ & Rp. $13,352,844$ \\
\hline Optimal total debt composition & Rp. $93,352,844$ \\
\hline Optimal percentage of debt & $23 \%$ \\
\hline \multicolumn{2}{|c|}{$\begin{array}{l}\text { UD.Hikmah use the composition of the capital structure compiled by debt of } 20 \% \text { and } 80 \% \text { of own } \\
\text { Judging from the optimization calculation table above, the composition of the optimal capital } \\
\text { re is found when the debt composition is } 23 \% \text { and capital is } 77 \% \text {. After calculating the composition of } \\
\% \text {, it will be the same as the use of } 0 \% \text { debt which can be said to be optimal because it can produce a } \\
\text { f profitability by providing returns that are beneficial to the owners of capital as measured by the } \\
\text { ROE of } 173 \% \text { and capital costs borne namely Rp. } 18.238 .000 \text { every year. }\end{array}$} \\
\hline
\end{tabular}


The cost of capital generated is slightly larger and the composition of the debt is increased, but with the use of larger debt, it can reduce the use of own capital, which is one form of problem faced by many MSMEs today, namely the limited access to internal capital. If the debt is enlarged, the business scale will be higher and the possibility will also get higher profitability. The capital structure used by UD. Hikmah in using the composition of debt is not more than $23 \%$, then the use of capital structure is said to be quite optimal because it is also in accordance with the proportion of ideal debt usage which is $\leq 35 \%$.

\section{CONCLUSION}

Based on the results of the research and discussion presented in the previous chapters, the following conclusions can be drawn:

1. The composition of the capital structure used by UD.Hikmah which consists of debt of Rp.80,000,000 and own capital of Rp.320,000,000.- or can be seen from the percentage composition of the capital structure used which is derived from debt $20 \%$ while that which comes from own capital $80 \%$. UD. Hikmah has a weighted average cost of capital $6.818 \%$ and the cost of capital to be borne is Rp.17,873,000, - every year.

2. Judging from the calculation of capital structure optimization, the optimal composition of capital structure is found when the debt composition is $23 \%$ and own capital is $77 \%$. After calculating the composition of debt $23 \%$, it will be the same as the use of $0 \%$ debt which can be said to be optimal because it can produce a level of profitability by providing returns that are beneficial to the owners of capital as measured by the highest ROE of $173 \%$ and capital costs borne namely Rp.18.238.000 every year.

\section{REFERENCES}

Ardiany, S., \& Topowijono, R. D. (2014). Analisis Penetapan Struktur Modal Yang Optimal Guna Meningkatkan Nilai Perusahaan (Studi Pada PT. Seemount Garden Sejahtera, Jiwan, Kabupaten Madiun Periode 2011-2013). Jurnal Administrasi Bisnis Agustus, 13(1), 1-10.

Britzelmaier, B., Kraus, P., Häberle, M., Mayer, B., \& Beck, V. (2013). Cost of capital in SMEs. EuroMed Journal of Business, 8(1), 4-16. https://doi.org/10.1108/emjb-05-2013-0017

David F. Scott, J. (2000). Dasar-Dasar Manajemen Keuangan (1st ed.). Salemba Empat.

Harahap (2015: 304). Analisis Laporan Keuangan. In Analisis Laporan Keuangan (2nd ed., p. 2). bandung: Alfabeta.

Holden, C. W. (2002). Spreadsheet Modeling in Corporate Finance, 161. Retrieved from http://www.amazon.com/dp/0130499056

Husnan Suad. (2000). Manajemen Keuangan Teori Dan Penerapan (Keputusan Jangka Panjang (4th ed.). 24 APRIL 2019.

James C.Van Horne, John M. Wachowicz, J. (2012). Prinsip-Prinsip Manajemen Keuangan. (Ema Sri Suhasi, Ed.) (13th ed.). Salemba Empat.

J. Fred Weston, T. E. C. (1996). Manajemen Keuangan (8th ed.). ERLANGGA.

Kuncoro, D. S., Hidayat, R. R., Administrasi, F. I., \& Brawijaya, U. (2014). Penetapan Struktur Modal Optimum Dalam Hubungannya, 16(1), 1-10.

Sugiyono. (2011). Metode Penelitian Kualitatif dan $R \& D$ Bandung: Alfabeta

Sugiyono. (2015). Metode Penelitian Kualitatif dan $R \& D$. In Metode Penelitian (p. 224). Bandung; Alfabeta

Suryana. (2012). Metodologi Penelitian : Metodologi Penelitian Model Prakatis Penelitian

Kuantitatif dan Kualitatif. Universitas Pendidikan Indonesia, 243. https://doi.org/10.1007/s13398-014-0173-7.2

Sutrisno, 2011: 150. Jurnal of Economic , Management. Jurnal of Economic, Management, 1(2), 
81. https://doi.org/17.55129/ekt.v0i0.243

Weston, J. F., \& Copeland, T. E. (1992). Manajemen Keuangan. In Manajemen Keuangan (9th ed., p. 125). Jakarta: Binarupa Aksara.

Weston, J. F., \& Copeland, T. E. (1996). Manajemen Keuangan (Kesembilan). Jakarta: Erlangga.

Yasir, J. R., Fuad, A., \& Wahida. (2018). Jurnal of Economic , Management and Accounting. Jurnal of Economic, Management and Accounting, 1(1), 34-41.

Yuliani, Y. Y. (2017). Analisis Struktur Modal Perusahaan Industri Makanan Dan Minuman Di Bursa Efek Indonesia. Ekspektra : Jurnal Bisnis Dan Manajemen, 1(2), 81. https://doi.org/10.25139/ekt.v0i0.135

Undang-Undang, N. 20. (2008). Government Regulation No. 20/2008. UU No. 20 Tahun 2008, (1), $1-31$. 